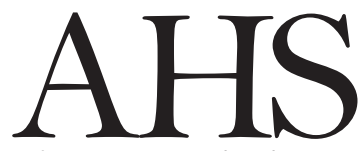

Advances in Horticultural Science
OPEN ACCESS

\footnotetext{
${ }^{(*)}$ Corresponding author:
}

aminekhoulati89@gmail.com

Citation:

KHOULATI A., SAALAOUI E., 2021 - Impact of Moroccan Crocus sativus L. tepals, corms, and stigmas extract on growth and photosynthetic pigments in tomato seedling. - Adv. Hort. Sci., 35(2): 207-213.

Copyright:

(c) 2021 Khoulati A., Saalaoui E. This is an open access, peer reviewed article published by Firenze University Press

(http://www.fupress.net/index.php/ahs/) and distributed under the terms of the Creative Commons Attribution License, which permits unrestricted use, distribution, and reproduction in any medium, provided the original author and source are credited.

Data Availability Statement:

All relevant data are within the paper and its Supporting Information files.

Competing Interests:

The authors declare no competing interests.

Received for publication 31 October 2020 Accepted for publication 9 April 2021

\section{Impact of Moroccan Crocus sativus L. tepals, corms, and stigmas extract on growth and photosynthetic pigments in tomato seedling}

\author{
A. Khoulati ${ }^{(*)}$, E. Saalaoui \\ Laboratory of Biochemistry and Biotechnology, Faculty of Sciences, \\ Mohammed First University, Oujda, Morocco.
}

Key words: Biostimulant, chlorophyll, Saffron by-product, Solanum lycopersicum L.

\begin{abstract}
An experiment was carried out in a greenhouse to study the effect of aqueous extracts of Crocus sativus L. by-products on tomato plants. Three concentrations of tepals and corms were used by fertigation: $1 \mathrm{~g} / \mathrm{L}, 2 \mathrm{~g} / \mathrm{L}$, and 3 $\mathrm{g} / \mathrm{L}$. The aqueous extract of the stigmas was used as a foliar application at $\mathbf{0 . 6}$ $\mathrm{g} / \mathrm{L}$. The experiment was carried out in a completely randomized block with three repetitions for each concentration. The concentration of tepal extract at 3 $\mathrm{g} / \mathrm{L}$ significantly ( $\mathrm{p} \leq 0.05$ ) increased the plants' height, the chlorophyll $a, b$ content in the leaf. The same results were observed for the foliar treatment with stigmas; however, there was no effect of tepal extract on the carotenoid content. On the other hand, the concentration $2 \mathrm{~g} / \mathrm{L}$ of the corms extract had a positive impact $(p \leq 0.05)$ in the chlorophyll b content while the concentration of $3 \mathrm{~g} / \mathrm{L}$ increased the plant's height, the chlorophyll a $(p \leq 0.05)$. Current results indicate that Crocus sativus by-products could improve certain physiological aspects of the recipient plants and be new and natural biostimulants.
\end{abstract}

\section{Introduction}

Saffron (Crocus Sativus L.) is a stemless, bulbous perennial plant that belongs to the Iridaceae family (Taylor et al., 2008). Moroccan surfaces grown from saffron are about 1000 ha, mainly in the mountains of the AntiAtlas. This production area takes more and more importance in other regions (Lage and Cantrell, 2009). In the production of saffron, for each kilogram of spices produced, about $53 \mathrm{~kg}$ of tepals are made (Maggi et al., 2012), and $90 \%$ of the total fresh weight corresponds to the by-products composed of tepals, which are generally discarded as waste (Menghini et al., 2018). Hundreds of corms too small for flowering to be replanted are dumped to obtain only $1 \mathrm{~kg}$ of dry stigmas (Smolskaite et al., 2011). However, this biomass is a potentially significant source of bioactive compounds. Many researchers have focused their attention on valuing saffron by-products to increase crop profitability, such as floral bio-residues and 
corms (Lahmass et al., 2018). The enhancement of these properties of saffron floral bio-residues was evaluated on the antioxidant activity (SanchezVioque et al., 2012), the anti-inflammatory activity (Amin and Hosseinzadeh, 2015), the antifungal and cytotoxic activity (Zheng et $a l ., 2011$ ), and antibacterial activity (Shadmehri et al., 2019). On the other hand, the tepals are used in many industries, as active ingredients in various food (Tuberoso et al. 2016), in cosmetic formulations (Natalia et al., 2019), and as a potential resource of natural color thanks to the high content of anthocyanins for food applications, and biomedical (Shadmehri et al., 2019). Bioactive components of corms include proteoglycans and saponins, which have shown antifungal and antioxidant activity (Rubio-Moraga et al., 2011). In a preliminary study, saffron stigmas showed a biostimulant and antifungal effect on the tomato plant (Khoulati et al., 2019). The applied treatments significantly improved plant height and positively affected the tomato fruit quality after enhancing the secondary metabolites' content.

These bioactive molecules of tepals and corms are supposed to have an effect biostimulant on recipients' plants. Therefore, the current study was planned to confirm the use of tepals and corms extract as a biostimulant on the morphological photosynthetic pigment parameters of tomato seedlings. The study will promote Crocus sativus L. by-product and produce new and natural biostimulants of plant growth.

\section{Materials and Methods}

\section{Plant material}

Tomato cultivar was sown in plastic trays until germination, at a temperature of $27^{\circ} \mathrm{C} \pm 2,70 \%$ relative humidity, photoperiod of $16 \mathrm{~h} / 8 \mathrm{~h}$ light/dark. At four leaves emergence, the seedlings were transferred to plastic pots $(33 \times 18 \mathrm{~cm})$ containing $60 \%$ sand, $35 \%$ peat (Floragard $50 / 50, v / v$ ), and $5 \%$ gravel and maintained at the optimum temperature (28/ $20^{\circ} \mathrm{C}$, day/ night) and natural daylight under greenhouse in the northeast of Morocco (34 $50^{\prime} 33^{\prime \prime} \mathrm{N}$, $\left.2^{\circ} 10^{\prime} 18^{\prime \prime} \mathrm{W}\right)$. The containers are placed on $100 \mathrm{~cm}$ apart rows and $60 \mathrm{~cm}$ within rows. There was no fertilizer application, and all the plants received the same volume of irrigation water.

One week later, the first treatment is applied. Tepals and corms extracts at three different concen- trations ( $1 \mathrm{~g} / \mathrm{L}, 2 \mathrm{~g} / \mathrm{L}$, and $3 \mathrm{~g} / \mathrm{L})$ were used both as fertigation with a $200 \mathrm{~mL}$ volume by one plant and $0.6 \mathrm{~g} / \mathrm{L}$ used foliar application by the saffron stigmas. Distilled water was taken as a control treatment. Each replicate set contained three seedlings, and the experiment had three replications in a completely randomized trial. After one week from the first application, the treatments were repeated, keeping the same concentration and method as the first application. One week after the second application, and when the biostimulant effect was visually observed, samples were collected to determine the morphological and photosynthetic pigment indices.

\section{Aqueous extract preparation}

Saffron stigmas originating from Taliouine (Morocco) were purchased, milled, and conserved at $-20^{\circ} \mathrm{C}$ until each use. The dried tepals were harvested during the 2019 production in the Tinissane region in the northeast of Morocco (34 $\left.50^{\prime} 33^{\prime \prime} \mathrm{N}, 2^{\circ} 10^{\prime} 18^{\prime \prime} \mathrm{W}\right)$. The tepals were milled and stored at $-20^{\circ} \mathrm{C}$ until each use. The corms were obtained from Taliouine and kept at $-20^{\circ} \mathrm{C}$ after drying. Before each application, the concentration of tepals and corms powder used for the study left $24 \mathrm{~h}$ in $1 \mathrm{~L}$ of distilled water for extraction in the dark for each concentration: $1 \mathrm{~g} / \mathrm{L}, 2$ $\mathrm{g} / \mathrm{L}$, and $3 \mathrm{~g} / \mathrm{L}$. For stigmas foliar application, $0.6 \mathrm{~g}$ extracted in $1 \mathrm{~L}$ of the distilled water $24 \mathrm{~h}$ in the dark.

\section{Quantification of the main components of extracts}

- The anthocyanin contents of tepals were measured according to the protocol explained by Ganjewala et al. (2008). The absorbance (Abs) of the samples was measured at $530 \mathrm{~nm}$, and the results were expressed in milligram equivalent cyanidin 3glucoside by 100 grams of dry matter (mg CGE/100g DM). Flavonol's contents were determined by measuring the absorbance at $360 \mathrm{~nm}$, and the results were expressed in milligram equivalent quercetin 3glucoside by 100 grams of dry matter (mg QGE/100g DM).

- The total polyphenol of tepals was determined using the Folin-Ciocalteu method (Velioglu et al., 1998). The total polyphenols concentrations were expressed in milligrams of gallic acid equivalent to 100 grams of dry matter (mg GAE/100 g DM).

- The content of crocin, picrocrocin, and safranal of saffron stigmas was determined following ISO 3632 (ISO, 2003).

\section{Morphological indices of tomato seedling}

Plant height was recorded using a measuring tape in $\mathrm{cm}$. Shoot fresh weight was measured immediately 
after rooting up the plants using an electronic balance. To determine the dry weight, samples were oven-dried for $24 \mathrm{~h}$ at $80^{\circ} \mathrm{C}$, and the value of the samples recorded in grams.

\section{Photosynthetic pigments}

The chlorophyll content and carotenoid were determined by crushing $0.2 \mathrm{~g}$ fresh leaf sample in 20 $\mathrm{mL}$ of $80 \%$ acetone and placed at room temperature for $48 \mathrm{~h}$ in the dark. A spectrophotometer was used to observe the absorbance at 663,645, and $652 \mathrm{~nm}$ of the samples (Lichtenthaler, 1987). Chlorophyll a, b, and total chlorophyll calculated using the following formula:

Chlorophyll a $(\mathrm{Chl}$ a) $=(12.7 \times$ Abs663) $-(2.69 \times$ Abs645 $)$

Chlorophyll b $(\mathrm{Chl} b)=(22.99 \times$ Abs645) $-(4.68 \times$ Abs663) Total chlorophyll $=\mathrm{Chl} \mathrm{a}+\mathrm{Chl} \mathrm{b}$

Total carotenoid content $=\frac{(1000 \text { Abs470 }-1.82 \mathrm{Chla}-85.02 \mathrm{Chlb})}{198}$

\section{Statistical analysis}

All figures and statistical analyses were performed using SPSS Statistics 17.0 software. The data were expressed as the mean \pm standard deviation (SD) of triplicate independent experiments and analyzed using a one-way analysis of variance (ANOVA). $p \leq 0.05$ was treated to be statistically significant. The Student-Newman-Keuls (SNK) test was used to classify averages using different letters for significant differences.

\section{Results}

\section{The main components of extracts}

The anthocyanins, flavonols, and polyphenols contents of tepals were $43.66 \pm 0.79 \mathrm{mg} \mathrm{CGE} / 100 \mathrm{~g} \mathrm{DM}$, $0.19 \pm 0.21 \mathrm{mg} \mathrm{QGE} / 100 \mathrm{~g} \mathrm{DM}$, and $672.73 \pm 1.02 \mathrm{mg}$
GAE/100 g DM, respectively. Total crocin, safranal and picrocrocin contents in the saffron sample are $184.56 \pm 2.19 \mathrm{mg} / \mathrm{g}, 4.89 \pm 0.18 \mathrm{mg} / \mathrm{g}$, and $62.43 \pm$ $0.37 \mathrm{mg} / \mathrm{g}$, respectively.

\section{Morphological indices}

Variations in the morphological data revealed the significant effect of tepals, corms, and stigma extracts on tomato seedling growth in terms of concentrations used (Figs. 1, 2). For the application of tepal extracts by fertigation, the highest plant height was recorded for plants fertigated with $3 \mathrm{~g} / \mathrm{L}$ followed by $2 \mathrm{~g} / \mathrm{L}$. In contrast, the lowest values were observed in

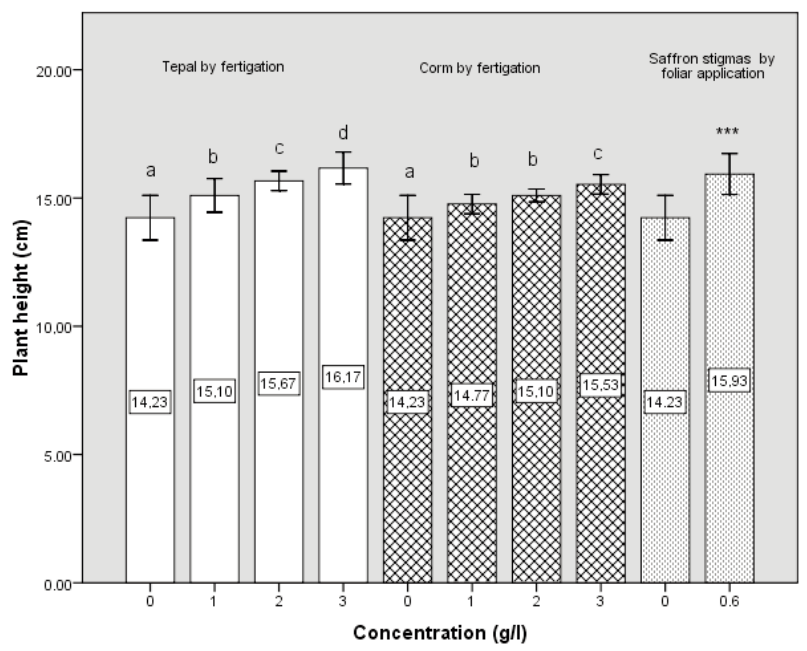

Fig. 1 - Saffron stigmas, tepals, and corms extracts affect the height of the tomato seedling. Measurements were made one week after the last treatment. Data were recorded for a total of three plants by treatment replicated three times. The concentration of saffron was represented as $0.6 \mathrm{~g} / \mathrm{L}$. The concentrations of tepals and corms are defined as $1 \mathrm{~g} / \mathrm{L}, 2 \mathrm{~g} / \mathrm{L}$, and $3 \mathrm{~g} / \mathrm{L}$. 0: control. Bars represent averages and error lines one standard deviation. The difference in the letters indicates significant differences at $\mathrm{p} \leq 0.05$ based on the SNK test. $* * *$ : the significative difference at $p \leq 0.001$.
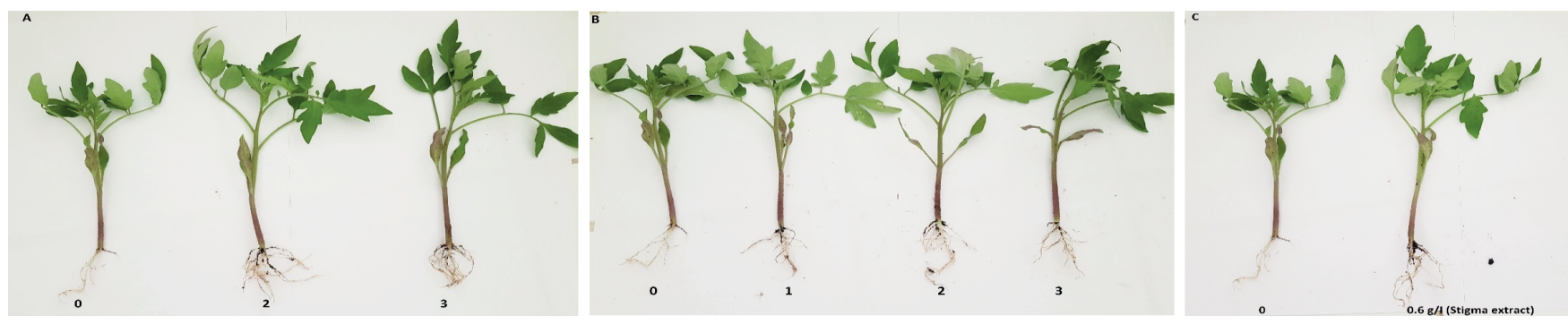

Fig. 2 - Tepal, corm, stigma extracts application to influence the tomato plant's plant height. The pictures were taken one week after the last treatment. 0 represents control treatment. A) treatment with petal extract by fertigation $(2 \mathrm{~g} / \mathrm{L}, 3 \mathrm{~g} / \mathrm{L})$. B) treatment with corm extract by fertigation ( $1 \mathrm{~g} / \mathrm{L}, 2 \mathrm{~g} / \mathrm{L}, 3 \mathrm{~g} / \mathrm{L})$. C) foliar application by saffron stigma extract at $0.6 \mathrm{~g} / \mathrm{L}$. 
control seedlings. Concerning the treatment of corms highest plant was recorded for plants fertigates with $3 \mathrm{~g} / \mathrm{L}$ followed by $2 \mathrm{~g} / \mathrm{L}$ and $1 \mathrm{~g} / \mathrm{L}$ compared to the control. However, the treatment by stigmas foliar application showed a significant difference at $p \leq 0.001$ compared to the control (Figs. 1,2 ). Table 1 represents fresh shoot weight, dry shoot weight, fresh root weight, and dry root weight. As compared to control, the fresh and dry weight of seedlings were increased with tepal application and reached a significant level at $2 \mathrm{~g} / \mathrm{L}$ followed by seedlings applied with $3 \mathrm{~g} / \mathrm{L}$. However, the same concentrations of applied tepal increased the weight of root fresh and root dry at $2 \mathrm{~g} / \mathrm{L}$, followed by $3 \mathrm{~g} / \mathrm{L}$. However, no effect of the application of the different concentrations of corm extract observed.

\section{Photosynthetic pigments}

The effect of tepals and corms on the chlorophyll contents of tomato leaves is depicted in figure 3. As it can be observed, the various applications influenced significantly enhanced the chlorophyll $a, b$, and total chlorophyll content. Concerning the use by tepal fertigation, the high value was recorded for the concentration of $3 \mathrm{~g} / \mathrm{L}$ with an increase of $45.96 \%$ for Chla and $28.71 \%$ for Chlb, compared to the control. The application by corm fertigation at $3 \mathrm{~g} / \mathrm{L}$ has increased Chla and Chlb concentrations of $37.12 \%$ and $15.22 \%$, respectively (Fig. 3), compared to the control. On the other hand, the three corm extract concentrations significantly increased the carotenoid content (Table 1). However, no effect was observed on the carotenoid content after fertigation by the three different tepals (Table 1 ).

For foliar application by saffron stigmas, the Chla, $\mathrm{Chlb}$, and carotenoid content significantly increased $11.59 \%$ for Chla, 56,84 \% for Chlb, and 55,69\% for
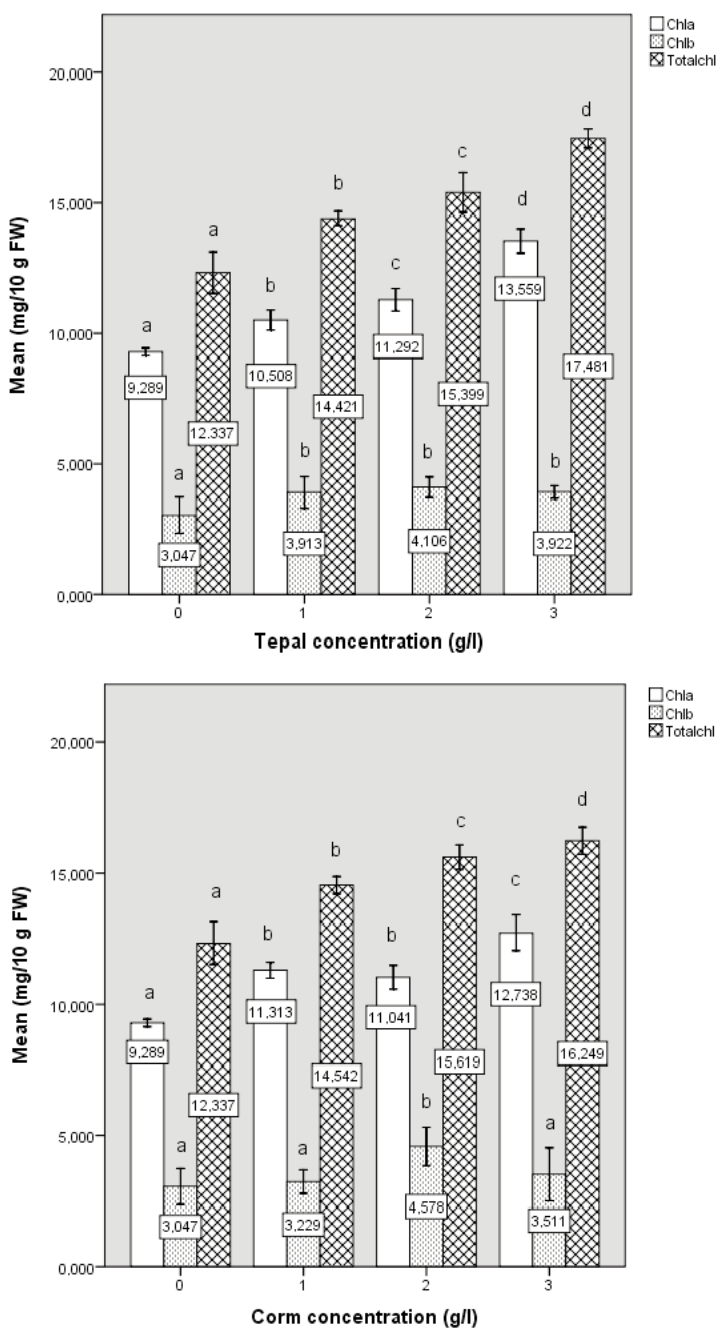

Fig. 3 - Effect of tepal and corm extract on pigment system of tomato leaves. Data are the mean \pm standard deviation of three replicates. The column followed by different letters shows a significant difference at $p \leq 0.05$ significance level between treatments according to the SNK test. FW= fresh weight. Chla= chlorophyll $a$; Chlb= chlorophyll b; Totalchl=: total chlorophyll. $0=$ control.letters are not significantly different, as determined by Tukey's test $(P<0.05)$.

Table 1 - Influence of tepal and corm application on the root and shoot weight of tomato plants and carotenoid leaves

\begin{tabular}{lcccccc}
\hline Application & $\begin{array}{c}\text { Concentration } \\
(\mathrm{g} / \mathrm{L})\end{array}$ & $\begin{array}{c}\text { Root fresh } \\
\text { weight } \\
(\mathrm{g})\end{array}$ & $\begin{array}{c}\text { Root dry } \\
\text { weight } \\
(\mathrm{g})\end{array}$ & $\begin{array}{c}\text { Shoot fresh } \\
\text { weight } \\
(\mathrm{g})\end{array}$ & $\begin{array}{c}\text { Shoot dry } \\
\text { weight } \\
(\mathrm{g})\end{array}$ & $\begin{array}{c}\text { Carotenoid } \\
(\mathrm{mg} / \mathrm{g} \mathrm{FW})\end{array}$ \\
\hline Control & 0 & $0.185 \pm 0.289 \mathrm{a}$ & $0.0192 \pm 0.004$ & $1.72 \pm 0.135 \mathrm{a}$ & $0.132 \pm 0.017$ & $2.431 \pm 0.108 \mathrm{a}$ \\
Tepal & 1 & $0.195 \pm 0.009 \mathrm{a}$ & $0.021 \pm 0.001^{*}$ & $1.68 \pm 0.355 \mathrm{a}$ & $0.118 \pm 0.036$ & $2.507 \pm 0.209$ \\
& 2 & $0.261 \pm 0.341 \mathrm{~b}$ & $0.0323 \pm 0.005^{*}$ & $2.641 \pm 0.564 \mathrm{~b}$ & $0.218 \pm 0.046^{*}$ & $2.703 \pm 0.335$ \\
& 3 & $0.212 \pm 0.013 \mathrm{a}$ & $0.0283 \pm 0.008^{*}$ & $2.332 \pm 0.156 \mathrm{ab}$ & $0.218 \pm 0.046 *$ & $2.985 \pm 0.337$ \\
& 1 & $0.138 \pm 0.427$ & $0.017 \pm 0.003$ & $1.436 \pm 0.613$ & $0.119 \pm 0.060$ & $2.98 \pm 0.652 \mathrm{~b}$ \\
& 2 & $0.141 \pm 0.018$ & $0.019 \pm 0.003$ & $1.516 \pm 0.548$ & $0.107 \pm 0.045$ & $2.889 \pm 0.147 \mathrm{~b}$ \\
& 3 & $0.142 \pm 0.519$ & $0.016 \pm 0.004$ & $1.495 \pm 0.591$ & $0.01 \pm 0.044$ & $2.708 \pm 0.15 \mathrm{~b}$ \\
\hline
\end{tabular}

The difference in the letters indicates significant differences at $p \leq 0.05$ based on the SNK test.

$*$ significative difference at $p \leq 0.05$.

$\mathrm{FW}=$ fresh weight. 
carotenoid (Fig. 4, Table 1). However, no significant difference was reported from the different tepal extract concentrations on the carotenoid content (Table 1). The different concentrations of the corm extract participated in the increase of the Chla and Chlb content but not in the same way as the tepal extracts; the highest value in Chla in plants treated with $3 \mathrm{~g} / \mathrm{L}$ of the extract corms is $12.73 \mathrm{mg} / 10 \mathrm{~g} \mathrm{FW}$ and while the highest value in Chla in plants treated with $3 \mathrm{~g} / \mathrm{L}$ of the tepal extract is $13.55 \mathrm{mg} / 10 \mathrm{~g} \mathrm{FW}$. However, a significant difference is observed in the carotenoid content of plants treated with extracts of corms, while this difference in carotenoid is absent in plants treated with tepal extracts. Chlorophyll content, especially Chlb of plants treated with the application of stigmas extract at $0.6 \mathrm{~g} / \mathrm{L}$, increased. The carotenoid content also increased after treatment with the stigma extract.

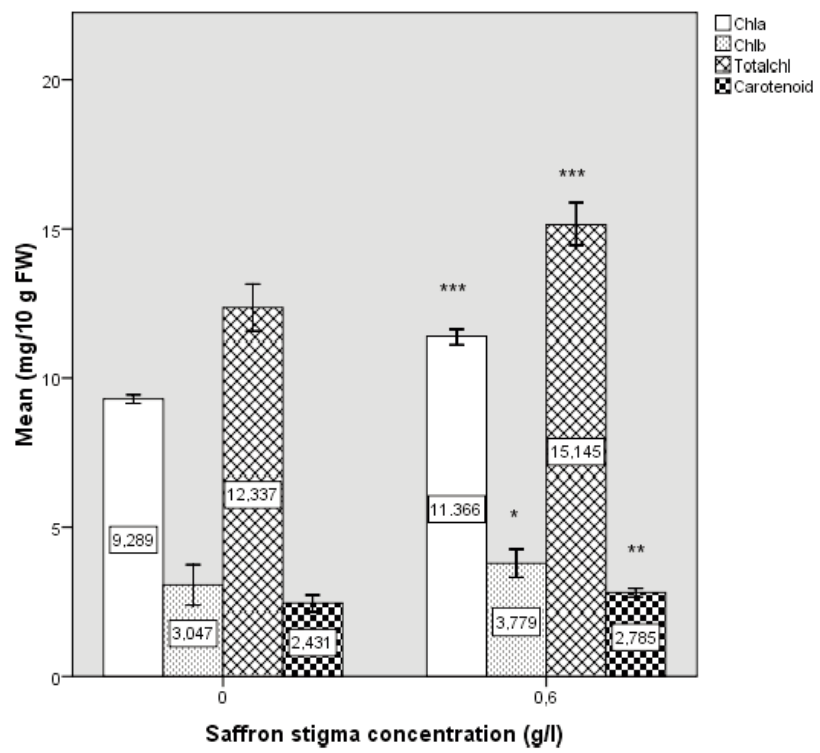

Fig. 4 - Effect of saffron stigmas on pigment system of tomato leaves by foliar application. Data are the mean \pm standard errors of three replicates. $* * *=$ the significative difference at $p \leq 0.001 .{ }^{*} 0$ the significative difference at $\mathrm{p} \leq 0.05$. $\mathrm{FW}=$ fresh weight. $\mathrm{Chla}=$ chlorophyll $\mathrm{a} ; \mathrm{Chl} \mathrm{b}=$ chlorophyll b; Totalchl= total chlorophyll. $0=$ control.

\section{Discussion and Conclusions}

The present study's objective was to valorize the tepals, corms, and stigmas of Crocus sativus L. and take advantage of its bioactive components to use them as a biostimulant alternative to chemicals products. Therefore, three tepals and corm extract $(1 \mathrm{~g} / \mathrm{L}$,
$2 \mathrm{~g} / \mathrm{L}$, and $3 \mathrm{~g} / \mathrm{L}$ ) are chosen to assess their effect by fertigation in some morphological and biochemical parameters of tomato seedling under greenhouse conditions in a completely randomized block.

The application of tepal, corm, and stigmas extracts has influenced the growth of the plant. Tepal has been reported as a protein source, fiber, fats, and essential minerals ( $\mathrm{K}, \mathrm{Ca}$, and $\mathrm{P}$ ) necessary for plants' growth (Fahim et al., 2012; Khazaei et al., 2016). Tepals are also rich sources of phenolic and biologically active compounds such as flavonoids (kaempferol, rutin, quercetin, luteolin, hesperidin, and bioflavonoids), tannins, and anthocyanins (Kanakis et al., 2006; Srivastava et al., 2010). The increased growth of tomato plants suggests that tepal extract may act as a promoter of plant growth with a $3 \mathrm{~g} / \mathrm{L}$ concentration, which contains $1.308 \mathrm{mg}$ CGE/L of anthocyanin and $20.181 \mathrm{mg} \mathrm{GAE} / \mathrm{L}$ of polyphenol. Corms also are a rich source of phenolic, flavonoid, and especially saponin (Rubio-Moraga et al., 2013), likely to participate in increased growth characteristics of the treated plants in the results of current research. Saffron stigmas contain nitrogenous substances, anthocyanins, glycosides, monoterpenes, aldehydes, flavonoids, vitamins, volatile oils, proteins, carbohydrates (Amin and Hosseinzadeh, 2015). Also, some studies indicated the presence of micro-nutrients in saffron such as $\mathrm{Zn}, \mathrm{Mn}$, and certain amino acids (Priscila del Campo et al., 2009; D'Archivio et al., 2014), which favored the development of the plant height and that the current results strongly corroborated with our previous study (Khoulati et al., 2019) with a concentration of $0.6 \mathrm{~g} / \mathrm{L}$, which contains $110.73 \mathrm{mg} / \mathrm{L}$ of crocin, $2.93 \mathrm{mg} / \mathrm{L}$ of safranal, and $37.45 \mathrm{mg} / \mathrm{L}$ of picrocrocin in the extract used in this study.

Photosynthesis is one of the primary processes of plant metabolism impacted by external conditions (Kalaji et al., 2017). Chlorophyll is a critical component of photosynthesis which absorbs sunlight (Hörtensteiner and Kräutler, 2011). It occurs in chloroplasts as green pigments in all photosynthetic plant tissues (Mazumder and Paul, 2014). Chla, the primary photosynthetic pigment of photosystems I and II, converts the energy of light. Chlb is an accessory pigment that absorbs light's energy (Petit et al., 2012).

On the other hand, carotenoids are also essential for plants because they protect the photosynthetic apparatus from light-mediated stress. Carotenoids participate in a wide range of physiological process- 
es, including growth, development, and plant responses to environmental stimuli, and protect plants against photo-oxidative damage (Racchi, 2013).

The application of tepal and corm extract by fertigation, and saffron extract by foliar application, significantly improved the chlorophyll content. The tepal extract increased the Chla content in a linear manner $\left(R^{2}=0.947\right)$; the increase in the Chla content correlated with the rise of the concentration of the tepal extract ( $r=0.973$ ) (Fig. 5). This increase in chlorophyll content may result from reduced chlorophyll degradation, which may be related mainly to polyphenol in the extract and many other molecules that can increase the pigment content. They can also activate enzymes responsible for the regulation and photosynthetic reduction of carbon and the chloroplast protection against oxidative damage. Also, they can include compounds that play a photoprotective role by scavenging reactive oxygen species. The exogenous application of biostimulant has been shown to activate specific genes involved in the transcription of proteins for photosynthetic processes (Trevisan et al., 2011) . However, higher chlorophyll content may involve growth stimulation and primary metabolic responses of treated plants compared to control plants (Shalaby and El-Ramady, 2014).

In this study, we concluded that the aqueous extract of tepals and corms at $3 \mathrm{~g} / \mathrm{L}$ had a bio-stimulatory effect on tomato plants. The use of these extracts in specialized horticulture practices such as organic farming may be a better solution to ensure

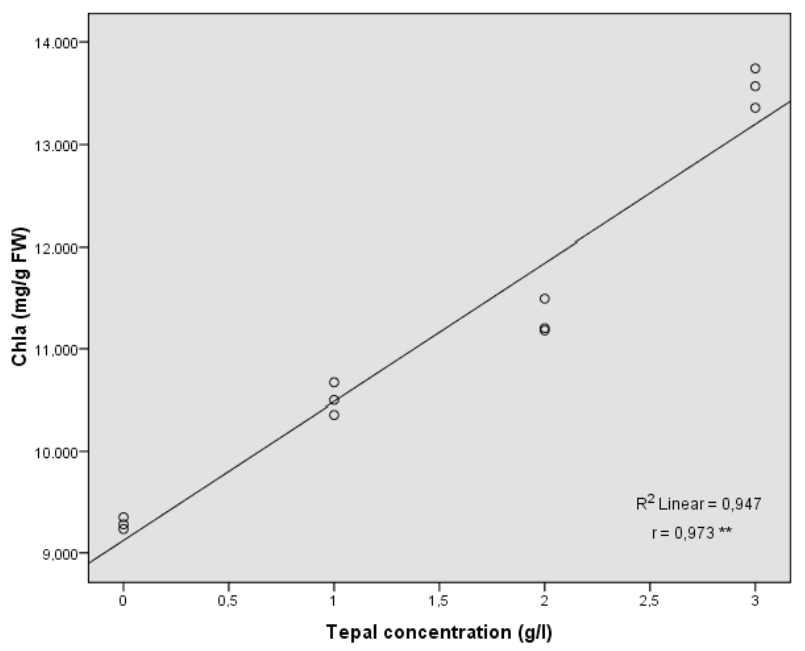

Fig. 5 - Linear regression curve between chlorophyll a, and the concentrations of tepal extracts. Chla $=$ chlorophyll a. ${ }^{* *}=$ correlation is significant at the 0.01 level. $\mathrm{R}^{2}=\mathrm{R}$-squared. quality performance and does not present risks for the user and the consumer. Besides, these results present an advantage for the farmer practicing the culture of Crocus sativus by recovering the waste which they throw before like tepals.

However, future research needed to explore the influence on the treated plants' primary and secondary metabolites provides a platform to elaborate and study the biological activity of the extracts inside the treated plants to identify and later confirm the molecular patterns involved in the bioactive mechanism of these extracts.

\section{Acknowledgements}

Authors express their thanks to Rayan Agricole, the ANPAM and the CNRST to participate in this study's realization.

\section{References}

AMIN B., HOSSEINZADEH H., 2015 - Analgesic and antiinflammatory effects of Crocus sativus L. (Saffron), pp. 319-324. - In: RONALD R.W., and R.P. VICTOR (eds.) Bioactive nutraceuticals and dietary supplements in neurological and brain disease. Academic Press, Cambridge, MA, USA, pp. 528.

D'ARCHIVIO A.A., GIANNITTO A., INCANI A., NISI S., 2014 Analysis of the mineral composition of Italian saffron by ICP-MS and classification of geographical origin. - Food Chem., 157: 485-489.

FAHIM N.K., JANATI S.S.F., FEIZY J., 2012 - Chemical composition of agriproduct saffron (Crocus sativus L.) petals and its considerations as animal feed. - GIDA, 37: 197201.

GANJEWALA D., BOBA S., RAGHAVENDRA A.S., 2008 Sodium nitroprusside affects the level of anthocyanin and flavonol glycosides in pea (Pisum sativum L. cv. Arkel) leaves. - Acta Biologica Szegediensis, 52: 301305.

HÖRTENSTEINER S., KRÄUTLER B., 2011 - Chlorophyll breakdown in higher plants. - Biochim. Biophys. Acta Bioenerg., 1807: 977-988.

ISO, 2003 - TS 3632-1/2. Technical specification. Crocus sativus L. Saffron. - International Organization for Standardization (ISO), Geneva, Switzerland.

KALAJI H.M., BABA W., GEDIGA K., GOLTSEV V., SAMBORSKA I.A., CENTER M.D., DIMITROVA S., PISZCZ U., BIELECKI K., KARMOWSKA K., DANKOV K., KOMPALA A., 2017 - Chlorophyll fluorescence as a tool for nutrient status identification in rapeseed plants. - Photosynth. Res., 136: 329-343. 
KANAKIS C.D., TARANTILIS P.A., POLISSIOU M.G., DIAMANTOGLOU S., TAJMIR-RIAHI H.A., 2006 - Antioxidant flavonoids bind human serum albumin. - J. Mol. Struct., 798: 69-74.

KHAZAEI K.M., JAFARI S.M., GHORBANI M., KAKHKI A.H., SARFARAZI M., 2016 - Optimization of anthocyanin extraction from saffron petals with response surface methodology. - Food Anal. Methods, 9(7): 1993-2001.

KHOULATI A., OUAHHOUD S., MAMRI S., ALAOUI K., LAHMASS I., CHOUKRI M., KHRAMACH EZ., ASEHRAOU A., SAALAOUI E., 2019 - Saffron extract stimulates growth, improves the antioxidant components of Solanum lycopersicum $L$., and has an antifungal effect. - Ann. Agric. Sci., 64: 138-150.

LAGE M., CANTRELL C.L., 2009 - Quantification of saffron (Crocus sativus L.) metabolites crocins, picrocrocin and safranal for quality determination of the spice grown under different environmental Moroccan conditions. Sci. Hortic, 121: 366-373.

LAHMASS I., SABIR O., MOHAMMED E., ASSIA S., MOHAMMED E., REDOUANE B., MOHAMMED C., ENNOUAMANE S., 2018 - Determination of antioxidant properties of six by-products of crocus sativus determination of antioxidant properties of six by-products of Crocus sativus L. (Saffron) plant products. - Waste Biomass Valorization, 9: 1349-1357.

LICHTENTHALER H.K., 1987 - Chlorophyll and carotenoids: Pigments of photosynthetic biomembranes, pp. 350382. - In: PACKER L., and R. DOUCE (eds.) Methods in Enzymology. Academic Press, San Diego, USA, pp. 609.

MAGGI L., MAGDALENA M., LUIS G., ANTONIA M.M., GONZALO L.A., JÉSSICA S.D., ANA M.S., 2012 - Increasing the applications of Crocus sativus flowers as natural antioxidants. - J. Food Sci., 77 (11).

MAZUMDER P.B., PAUL S.B, 2014 - Effect of copper on growth and chlorophyll content in tea plants (Camellia sinensis (L.) O. Kuntze). - Int. J. Res. Appl., Natural Social Sci. IJRANSS, 2(5): 223-230.

MENGHINI L., LEPORINI L., VECCHIOTTI G., LOCALTELLI M., CARRADORI S., FERRANTE C., ZENGIN G., RECINELLA L., CHIAVAROLI A., LEONE S., BRUNETTI L., ORLANDO G., 2018 - Crocus sativus $L$. stigmas and by-products: Qualitative fingerprint, antioxidant potentials and enzyme inhibitory activities. - Food Res. Int., 109: 9198.

NATALIA M., MARÍA J.B., CÁNDIDA L., MARTÍNEZ-NAVARRO M.E., ROSARIO S.M., GONZALO L.A., 2019 Bioactivity and bioavailability of the significant bioactivity and bioavailability of the major metabolites of Crocus sativus L. flower. - Molecules, pp. 1-24.

PETIT A.N., FONTAINE F., VATSA P., CLEMENT C., VAILLANT-GAVEAU N., 2012 - Fungicide impacts on photosynthesis in crop plants. - Photosynth. Res., 111: 315-326.

PRISCILA DEL CAMPO C., GARDE-CERDÁN T., SÁNCHEZ A.M., MAGGI L., CARMONA M., ALONSO G.L., 2009 Determination of free amino acids and ammonium ion in saffron (Crocus sativus L.) from different geographical origins. - Food Chem., 114: 1542-1548.

RACCHI M.L., 2013 - Antioxidant defenses in plants with attention to Prunus and Citrus spp. - Antioxidants, pp. 340-369.

RUBIO-MORAGA Á., GERWIG G.J., CASTRO-DIAZ N., LUISA M., ESCRIBANO J., FERNANDEZ J., KAMERLING J.P., 2011 - Triterpenoid saponins from corms of Crocus sativus: Localization, extraction and characterization. Ind. Crop. Prod., 34: 1401-1409.

RUBIO-MORAGA Á., GÓMEZ-GÓMEZ L., TRAPERO A., 2013 - Saffron corm as a natural source of fungicides: The role of saponins in the underground. - Ind. Crop. Prod., 49: 915-921.

SANCHEZ-VIOQUE R., RODRIGUES-CONDE M.F., REINAURENA J.V., ESCOLANO-TERCERO M.A., HERRAIZPENALVER D., SANTANA-MERIDAS O., 2012 - In vitro antioxidant and metal chelating properties of corm, petal and leaf from saffron (Crocus sativus L.). - Ind. Crop. Prod., 39: 149-153.

SHADMEHRI A.A., FARIDEH N., HAMIDREZA M., PARICHEHRE Y., MAHBOOBEH N., 2019 - Cytotoxicity, antioxidant and antibacterial activities of Crocus sativus petal extract. - Int. J. Res. Med. Sci., 5(1): 69-76.

SHALABY T.A., EL-RAMADY H., 2014 - Effect of foliar application of bio-stimulants on growth, yield, components, and storability of garlic (Allium sativum L .). - Aust. J. Crop Sci., 8: 271-275.

SMOLSKAITE L., TALOU T., FABRE N., VENSKUTONIS P.R., 2011 - Volarization of saffron industry by-products: bioactive compounds from leaves. - FOODBALT, pp. 6772.

SRIVASTAVA R., AHMED H., DIXIT R.L, SARAF S.A., 2010 Crocus sativus L.: A comprehensive review. Pharmacogn. Rev., 4(8): 200-208.

TAYLOR P., KUMAR R., SINGH V., DEVI K., SHARMA M., SINGH M.K., AHUJA, P.S., 2008 - State of art of saffron (Crocus sativus L.) agronomy: A comprehensive review. - Food Rev. Int., 25(1).

TREVISAN S., BOTTON A., VACCARO S., VEZZARO A., QUAGGIOTTI S., NARDI S., 2011 - Humic substances affect arabidopsis physiology by altering the expression of genes involved in primary metabolism, growth and development. - Environ. Exp. Bot., 74: 45-55.

TUBEROSO C.I.G., ANTONELLA R., PAOLA M., MAURIZIO A., COSIMO P., 2016 - Antioxidant activity, cytotoxic activity and metabolic profiling of juices obtained from saffron (Crocus sativus $L$.) floral by-products. - Food Chem., 199: 18-27.

VELIOGLU Y.S., MAZZA G., GAO L., OOMAH B.D., 1998 Antioxidant activity and total phenolics in selected fruits, vegetables, and grain products. - J. Agric. Food Chem., 46(10): 4113-4117.

ZHENG C., LIN L., WEN-HUI M., TING H., LU-PING Q., 2011 Chemical constituents and bioactivities of the liposoluble fraction from different medicinal parts of Crocus sativus. - Pharm. Biol., 49: 756-763. 
